\title{
Effectiveness evaluation of radiosynovectomy on the radiological progression of osteoarthritis of the knee joint
}

\author{
Radyosinovektominin diz eklemi osteoartritinin radyolojik ilerlemesi \\ üzerindeki etkililiğinin değerlendirilmesi
}

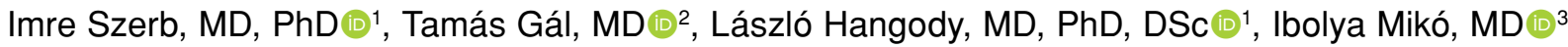 \\ 'Department of Orthopaedics and Traumatology, Uzsoki Hospital, Budapest \\ ${ }^{2}$ Department of Traumatology, Semmelweis University, Budapest \\ ${ }^{3}$ National Institute of Rheumatology and Physiotherapy, Budapest
}

\begin{abstract}
Objectives: This study aims to analyze the effect of radiosynovectomy (RSO) on the radiological progression of osteoarthritis of the knee joint.

Patients and methods: The study included 207 knee joints of 181 patients (72 males, 109 females; mean age 58 years; range, 19 to 65 years) that were performed RSO between 01 April 2003 and 31 December 2015 in the Department of Orthopedics and Traumatology at Uzsoki Hospital. A total of 111 right and 96 left knees were treated. The mean duration of follow-up was 8.7 years (range, 1 to 12 years). Of the 181 patients, both knee joints were treated in 26 .

Results: Of the 207 treated knee joints, 163 had the same Kellgren-Lawrence grade at the time of follow-up compared to the grade at the time of RSO, while 44 had worse outcomes. This indicated that radiological progression was not present in $79 \%$ of the treated knee joints. The intraclass correlation coefficient (ICC) showed significantly strong agreement between the pre- and post-measurements ( $\mathrm{ICC}=0.835$, $\mathrm{p}<0.001)$.
\end{abstract}

Conclusion: Radiosynovectomy was able to impede radiological progression in $79 \%$ of the treated joints and only one-grade deterioration was observed in 39 cases during follow-up.

Keywords: Osteoarthritis; radiosynovectomy; synovectomy; synovitis.

\section{ÖZ}

Amaç: Bu çalışmada radyosinovektomi (RSO)'nin diz eklemi osteoartritinin radyolojik ilerlemesi üzerindeki etkililiği incelendi.

Hastalar ve yöntemler: Çalışmaya 01 Nisan 2003 ve 31 Aralık 2015 tarihleri arasında Uzsoki Hastanesi Ortopedi ve Travmatoloji Bölümünde RSO uygulanan 181 hastanın (72 erkek, 109 kadın; ort. yaş 58 yıl; dağılım, 19-65 yıl) 207 diz eklemi dahil edildi. Toplam 111 sağ ve 96 sol diz tedavi edildi. Ortalama takip süresi 8.7 yıl (dağılım, 1-12 yıl) idi. Yüz seksen bir hastanın 26'sında her iki diz eklemi tedavi edildi.

Bulgular: Tedavi edilen 207 diz ekleminden 163'ü takip zamanında RSO zamanındaki evreye göre aynı Kellgren-Lawrence evresine sahipken 44'ü daha kötü sonuçlara sahipti. Bu, tedavi edilen diz eklemlerinin \%79'unda radyolojik ilerleme olmadığına işaret etti. Sınıf içi korelasyon katsayısı (ICC) önceki ve sonraki ölçümler arasında anlamlı şekilde güçlü uyum gösterdi ( $\mathrm{ICC}=0.835$, $\mathrm{p}<0.001)$.

Sonuç: Radyosinovektomi tedavi edilen eklemlerin \%79'unda radyolojik ilerlemeyi önleyebildi ve takipte 39 olguda sadece bir evre kötüleşme gözlemlendi.

Anahtar sözcükler: Osteoartrit; radyosinovektomi; sinovektomi; sinovit. 
Synovitis is the term for inflammation of the synovial membrane due to various pathological causes. In recent years, the modern conception of osteoarthritis development, also through imaging methods, has fundamentally influenced our understanding of the importance of synovitis, subchondral bone changes, pathological alterations in the joint capsule and tendons. ${ }^{[1]}$ It became evident that the inflammatory process of the synovial membrane is already underway in the joint when no degenerative alteration of the hyaline cartilage can be detected. Later on, the inflamed synovial membrane creeps over the surface of the articular cartilage and by producing inflammatory cytokines, among other things, causes cartilage damage. That is why treatment of synovitis is of great significance, since it aims to relieve pain, stop tension of the articular capsule and functional impairment of the joint, ${ }^{[2]}$ furthermore, to prevent cartilage damage and osteoarthritis, a very common condition. The prevalence of osteoarthritis is continuously increasing and it is going to become the most important factor of disability due to musculoskeletal disorders by 2030. ${ }^{[3]}$ Based on the international literature, radiosynovectomy (or radiosynoviorthesis) (RSO) is suitable for eliminating synovitis in the treated joints. ${ }^{[4]}$ Therefore, in this study, we aimed to analyze the effect of RSO on the radiological progression of osteoarthritis of the knee joint.

\section{PATIENTS AND METHODS}

A total of 773 RSOs in various joints were performed between 01 April 2003 and 31 December 2015 in the Department of Orthopedics and Traumatology at Uzsoki Hospital. This means 684 patients, since more than one joint was treated in 89 patients. Radiosynovectomy of the knee joint was carried out in 476 cases. A relatively smaller proportion of patients undergoing RSO of the knee came for follow-up evaluation, despite trying to contact them through phone calls, e-mails and letter notifications. Thereby, 207 treated knee joints in 181 patients (72 males, 109 females; mean age 58 years; range, 19 to 65 years) were available for follow-up. The mean time to follow-up was 8.7 years (range, 1 to 12 years). In 26 out of 181 patients, both knee joints were treated. Those who required repeated RSO of the same knee joint were excluded. Otherwise, there were 27 of them in the population mentioned earlier. The study protocol was approved by the Uzsoki Hospital Ethics Committee. A written informed consent was obtained from each patient. The study was conducted in accordance with the principles of the Declaration of Helsinki.

Severity of osteoarthritis seen on X-ray images was assessed by using the Kellgren-Lawrence classification scale (Table I). ${ }^{[5]}$ Radiosynovectomy involves an intraarticular injection of a radionucleotide to cause sclerosis of the synovia. Many factors determine the type of isotope to be administered. First, the size of the treated joint, the average amount and the thickness of the synovia all have to be considered. The latter can be accurately defined by ultrasound examination or magnetic resonance imaging. Furthermore, the mean halflife and the tissue penetration of the used isotope also have to be considered. As $\beta$-radiation is less tissue penetrating than $\gamma$-radiation, $\beta$-emitting isotopes should be preferred. Therefore, the patient and his/her environment will not be exposed to radiation poisoning. In our practice and worldwide, isotope Yttrium-90, used for the treatment of knee joint, has a half-life of 2.7 days, and its average tissue penetrating ability is $2.8 \mathrm{~mm}$ (maximum $11 \mathrm{~mm}$ ).

During RSO, $5 \mathrm{mCi}(185 \mathrm{mBq})$ of Yttrium-90 radiocolloid is injected into the knee joint. The procedure is carried out in the orthopedic theatre,

\section{TABLE I}

Kellgren-Lawrence classification scale for radiological assessment of osteoarthritis

\begin{tabular}{|c|c|c|}
\hline & Kellgren-Lawrence & Modified Kellgren-Lawrence \\
\hline Grade 0 & No radiographic features of osteoarthritis are present & No radiographic features of osteoarthritis are present \\
\hline Grade 1 & $\begin{array}{l}\text { Doubtful narrowing of joint space and possible } \\
\text { osteophytic lipping }\end{array}$ & Doubtful osteophyte formation \\
\hline Grade 2 & $\begin{array}{l}\text { Definite osteophyte formation and possible joint space } \\
\text { narrowing }\end{array}$ & Definite osteophyte formation \\
\hline Grade 3 & $\begin{array}{l}\text { Moderate multiple osteophytes, definite joint space } \\
\text { narrowing, mild sclerosis and bone deformity possible }\end{array}$ & Joint space narrowing \\
\hline Grade 4 & $\begin{array}{l}\text { Large osteophytes, marked joint space narrowing, } \\
\text { severe sclerosis and definite bony deformity }\end{array}$ & Virtual disappearance of joint space ("bone on bone") \\
\hline
\end{tabular}


under local anesthesia; 1\% Lidocain is used for this purpose. 23-G needle is used for the injection into the joints. The first step of the procedure is aspiration of the intraarticular fluid. Following removal of the synovia, the syringe is detached, leaving the needle in place. Subsequently, the contents of the radioisotopeloaded syringe is slowly injected into the knee joint; then, at the end of the intervention, a mixture of $1 \%$ Lidocain and Triamcinolone are injected into the treated joint. This is to prevent the possible synovitis caused by the isotope-colloid suspension itself. The knee joint is immobilized in a brace for 48 hours. Patients are kept on bed rest for 48 hours. Joint immobilization after the procedure is an important measure to minimize leakage of the isotope-colloid from the joint.

When performed properly, RSO has a very low rate of side effects and complications. The risk of infection after RSO is very small (1:35 000). The most common adverse effect is intensification of inflammatory symptoms (radiosynovitis) within 2-4 weeks after RSO. The most dramatic complication of RSO takes the form of extensive skin and muscle necrosis due to extra-articular injection or leakage. ${ }^{[6]}$

Radiosynovectomy was performed in stages 0,1 and 2 according to the aforementioned classification, as it is known from the literature that this intervention is ineffective in the more advanced stages of osteoarthritis. ${ }^{[7]}$ In this case, RSO can eliminate symptoms related to synovitis, but clinical symptoms and complaints associated with advanced osteoarthritis certainly persist.

\section{Statistical analysis}

The R 3.4.1. version (2017) Statistical Software ( $\mathrm{R}$ Foundation for Statistical Computing, Vienna, Austria) was used for statistical analysis. The significance level was set at $\mathrm{p}<0.05$ whereas an effect was considered a trend when $p$ was between 0.05 and 0.10 . The presence of radiological progression was tested by intraclass correlation coefficient (ICC). Intraclass correlation coefficient estimates and their 95\% confidence intervals (CIs) were calculated based on an absolute-agreement, two-way model (package irr in R). The differences in radiological progression among the grades 0,1 and 2 were tested by relative risk analysis (package epitools in R).

\section{RESULTS}

Distribution of the 181 patients by diagnosis was as follows: early stage of osteoarthritis (Kellgren-Lawrence grades 0-1-2) with synovitis in 34 patients, rheumatoid arthritis with knee synovitis in 63 patients, psoriatic arthritis in 38 patients, ankylosing spondylitis with peripheral synovitis in 39 patients, and pigmented villonodular synovitis (PVNS) in seven patients. It should be noted that in PVNS cases, arthroscopic synovectomy was first carried out for the sake of correct diagnosis that requires histologic examination. Radiosynovectomy was performed following the unsuccessful surgical synovectomy.

None of the patients showed better outcome on the Kellgren-Lawrence scale at the time of the follow-up evaluation than at the time of the intervention. The average time to follow-up was 8.7 years (range, 1 to 12 years). 163 out of 207 treated knee joints revealed the same Kellgren-Lawrence grade at the time of the follow-up compared to the grade at the time of RSO, while 44 knee joints progressed (Figure 1).

Intraclass correlation coefficient showed strong significant agreement between pre- and posttreatment Kellgren-Lawrence grades (ICC $=0.835$, 95\% CIs were: 0.713-0.897, $\mathrm{p}<0.001$ ).

Of the 55 joints belonging radiologically to grade 0 at the time of the intervention, 42 remained in this group, which means $23.6 \%$ deteriorated with one grade. Of the joints belonging to grade 1 on the Kellgren-Lawrence scale at the time of the
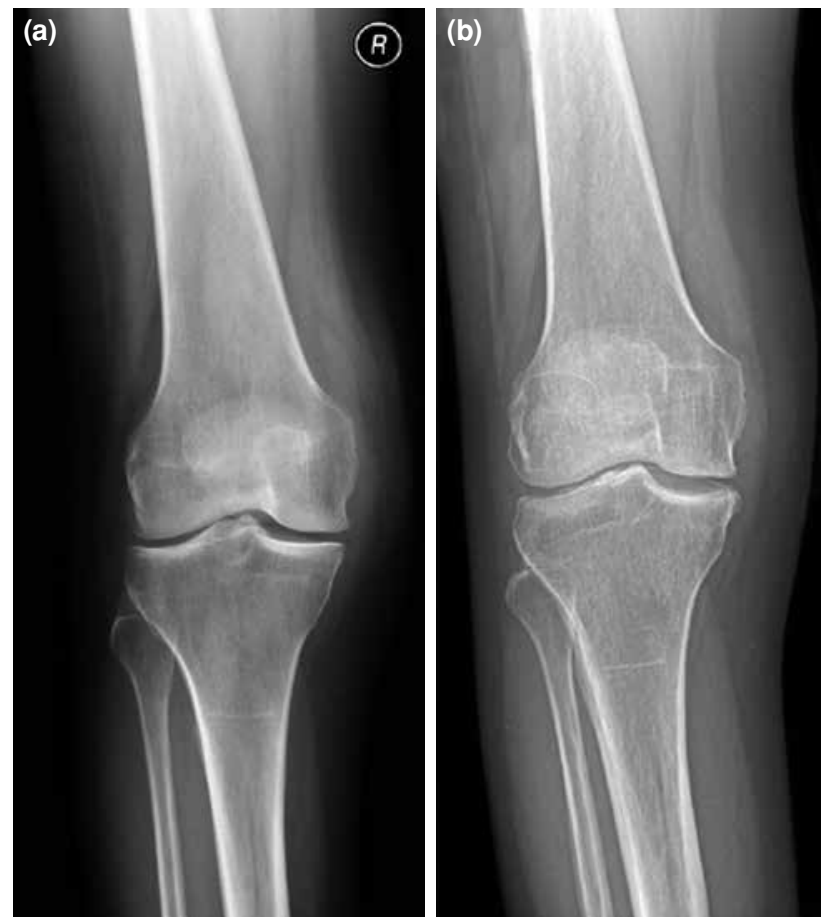

Figure 1. (a) Weight-bearing knee X-ray at time of radiosynovectomy. (b) Same knee 15 months after radiosynovectomy, with one-grade worsening. 


\section{TABLE ॥}

Evaluation of radiological progression after radiosynovectomy of knee joint

\begin{tabular}{|c|c|c|c|c|c|c|}
\hline \multirow[b]{2}{*}{$\begin{array}{l}\text { Number of knee joints at the time of } \\
\text { the intervention }\end{array}$} & \multicolumn{5}{|c|}{ Number of knee joints at the time of the follow-up } & \multirow[b]{2}{*}{$\begin{array}{l}\text { Total } \\
\text { (at the time of the intervention }\end{array}$} \\
\hline & Grade 0 & Grade 1 & Grade 2 & Grade 3 & Grade 4 & \\
\hline Grade 0 & 42 & 13 & 0 & 0 & 0 & 55 \\
\hline Grade 1 & 0 & 31 & 12 & 0 & 0 & 43 \\
\hline Grade 2 & 0 & 0 & 90 & 14 & 5 & 109 \\
\hline Total (at follow-up) & 42 & 44 & 102 & 14 & 5 & 207 \\
\hline
\end{tabular}

intervention, $27.9 \%$ (12 out of 43 ) showed a one-grade deterioration at follow-up. Fourteen out of 109 of the joints belonging to grade 2 on the Kellgren-Lawrence scale at the time of the intervention showed a onegrade, while five showed a two-grade deterioration at follow-up. Therefore, in total, $17.4 \%$ deteriorated with at least one grade (Table II).

Relative risk analysis did not show significant differences among the different grades at the time of intervention regarding the presence of deterioration with at least one grade at follow-up ( $p>0.1$ in all cases). However, deterioration with two grades was only present among joints belonging to grade 2 on the Kellgren-Lawrence scale at the time of intervention (in five cases) resulting a trend toward significance $(p=0.061)$. This suggests a higher risk of deterioration with two grades among grade 2 joints on the KellgrenLawrence scale at the time of intervention compared to grade 0 and 1 joints.

\section{DISCUSSION}

An excellent way to evaluate the response of RSO is using an objective parameter, e.g. the uptake of the radioisotope in the blood pool phase of the ${ }^{99} \mathrm{mTechnetium}$-methylene diphosphonate $\left({ }^{99} \mathrm{mTc}-\mathrm{MDP}\right)$ scan. Zuderman et al. ${ }^{[8]}$ measured the differences in ${ }^{99} \mathrm{mTc}-\mathrm{MDP}$ uptake before and after RSOs in 139 patients with 424 treated joints. A significant reduction in uptake was observed in medium-sized (knee) joints in $69 \%$ of patients. An increased uptake in the blood pool phase is a sign for synovitis. The absence of ${ }^{99} \mathrm{mTc}-\mathrm{MDP}$ uptake proves the elimination of synovitis in the treated joint.

A meta-analysis including 2,190 treated joints reported an average response rate of $73 \pm 17 \%$ for RSO. ${ }^{[9]}$ The highest response rate was observed in hemophilic arthritis $(91 \pm 4 \%)$, which was also confirmed by other studies. ${ }^{[10,11]}$

Based on these literary data, if we accept the fact that RSO eliminates the existing synovitis in the treated joints, does it also mean that progression of osteoarthritis decreases in these joints?

A retrospective clinical analysis was performed to answer this question. Since obtaining an X-ray of the joint before the intervention is a criterion of RSO, it was no problem at the follow-up to compare the images obtained at two different times, i.e. during treatment and at the follow-up, and furthermore, to evaluate any possible progression.

We were able to carry out the control of 207 knee joints in 181 patients. 163 out of 207 knee joints (79\%) revealed an unchanged grade on the KellgrenLawrence scale at the time of the follow-up, with an average 8.7 years after the RSO.

According to the literature, in $40 \%$ of patients with moderate knee osteoarthritis, there was no deterioration in radiological appearance without treatment after 30 months of follow-up. ${ }^{[12]}$ In our study, RSO could protect twice as many knee joints from developing osteoarthritis compared to that if the knee joints were left untreated. In the above-mentioned study, the follow-up time was only 2.5 years compared to 8.7 years in our study. ${ }^{[13]}$

No more than 44 joints showed an unfavorable outcome: in 39 cases a one-grade and in five cases a two-grade deterioration were discovered. It should be stressed that all five patients who showed a twograde radiological progression at follow-up belonged to grade 2 group at the time of the intervention, meaning that definite osteophyte formation was detected on their X-ray. In other words, the radiological status at the follow-up deteriorated mostly when RSO was performed in the most advanced stages.

Compared to surgical synovectomies, RSOs are much less costly. In the USA, the average cost of RSO is approximately US\$3,000, compared to US $\$ 61,000$ for surgical synovectomy. ${ }^{[14]}$ 
In conclusion, RSO was able to impede radiological progression in $79 \%$ of the treated joints. Thus, RSO is an effective and inexpensive treatment method for patients suffering from chronic knee synovitis.

\section{Declaration of conflicting interests}

The authors declared no conflicts of interest with respect to the authorship and/or publication of this article.

\section{Funding}

The authors received no financial support for the research and/or authorship of this article.

\section{REFERENCES}

1. Atik OŞ, Erdoğan D, Seymen CM, Bozkurt HH, Kaplanoğlu GT. Is there crosstalk between subchondral bone, cartilage, and meniscus in the pathogenesis of osteoarthritis? Eklem Hastalik Cerrahisi 2016;27:62-7.

2. Roch-Bras F, Daurès JP, Legouffe MC, Sany J, Combe B. Treatment of chronic knee synovitis with arthroscopic synovectomy: longterm results. J Rheumatol 2002;29:1171-5.

3. Thomas E, Peat G, Croft P. Defining and mapping the person with osteoarthritis for population studies and public health. Rheumatology (Oxford) 2014;53:338-45.

4. Rodriguez-Merchan EC. Aspects of current management: orthopaedic surgery in haemophilia. Haemophilia 2012;18:8-16.

5. Kellgren JH, Lawrence JS. Radiological assessment of osteo-arthrosis. Ann Rheum Dis 1957;16:494-502.

6. Modder G. Radiosynoviorthesis. Meckenheim: Warlich Druck und Verlagsges; 2001. p. 31-49.

7. Nacca CR, Harris AP, Tuttle JR. Hemophilic Arthropathy. Orthopedics 2017;40:e940-e946.

8. Zuderman L, Liepe K, Zöphel K, Andreeff M, Kotzerke J, Luboldt W. Radiosynoviorthesis (RSO): influencing factors and therapy monitoring. Ann Nucl Med 2008;22:735-41.

9. Kresnik E, Mikosch P, Gallowitsch HJ, Jesenko R, Just H, Kogler D, et al. Clinical outcome of radiosynoviorthesis: a meta-analysis including 2190 treated joints. Nucl Med Commun 2002;23:683-8.

10. Siegel HJ, Luck JV Jr, Siegel ME, Quinones C. Phosphate-32 colloid radiosynovectomy in hemophilia: outcome of 125 procedures. Clin Orthop Relat Res 2001;392:409-17.

11. Mathew P, Talbut DC, Frogameni A, Singer D, Chrissos M, Khuder S, et al. Isotopic synovectomy with P-32 in paediatric patients with haemophilia. Haemophilia 2000;6:547-55.

12. Sheehy L, Culham E, McLean L, Niu J, Lynch J, Segal NA, et al. Validity and sensitivity to change of three scales for the radiographic assessment of knee osteoarthritis using images from the Multicenter Osteoarthritis Study (MOST). Osteoarthritis Cartilage 2015;23:1491-8.

13. Atik OŞ. Are all case reports worth publishing? Eklem Hastalik Cerrahisi 2016;27:61.

14. Silva M, Luck JV Jr, Siegel ME. 32P chromic phosphate radiosynovectomy for chronic haemophilic synovitis. Haemophilia 2001;7 Suppl 2:40-9. 